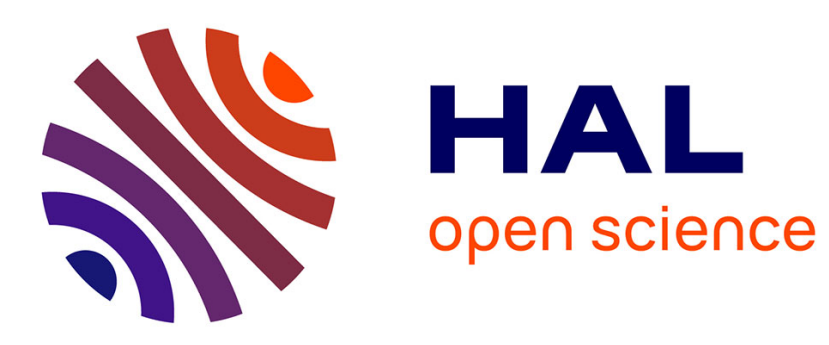

\title{
Phosphoproteomic Analysis of Isolated Mitochondria in Yeast
}

Margaux Renvoisé, Ludovic Bonhomme, Marlene Davanture, Michel Zivy, Claire Lemaire

\section{- To cite this version:}

Margaux Renvoisé, Ludovic Bonhomme, Marlene Davanture, Michel Zivy, Claire Lemaire. Phosphoproteomic Analysis of Isolated Mitochondria in Yeast. Aik-Choon Tan; Paul H.Huang. Kinase signaling networks, 1636, Springer Protocols, pp.283-299, 2017, Methods in Molecular Biology, 9781493971527. 10.1007/978-1-4939-7154-1_18. hal-02363352

\section{HAL Id: hal-02363352 \\ https://hal.science/hal-02363352}

Submitted on 30 Jan 2020

HAL is a multi-disciplinary open access archive for the deposit and dissemination of scientific research documents, whether they are published or not. The documents may come from teaching and research institutions in France or abroad, or from public or private research centers.
L'archive ouverte pluridisciplinaire HAL, est destinée au dépôt et à la diffusion de documents scientifiques de niveau recherche, publiés ou non, émanant des établissements d'enseignement et de recherche français ou étrangers, des laboratoires publics ou privés. 


\section{Phosphoproteomic analysis of isolated mitochondria in yeast}

Margaux Renvoisé ${ }^{1}$, Ludovic Bonhomme ${ }^{2}$, Marlène Davanture ${ }^{3}$, Michel Zivy ${ }^{3}$ and Claire Lemaire $^{1 *}$

1 : UMR 9198 CNRS,Institute for Integrative Biology of the Cell ( I2BC), B3S, LPSM - CEA Saclay - 91191 Gif-sur - Yvette cedex, France

2: INRA-UBP, UMR 1095, Genetics, Diversity and Ecophysiology of Cereals, F-63039 Clermont-Ferrand, France.

3: CNRS, PAPPSO, Génétique Quantitative et Evolution - le Moulon, F-91191 Gif-surYvette, France.

*Corresponding author

$\underline{\text { claire.lemaire@i2bc.paris-saclay.fr }}$ 
Summary

Mitochondria play a central role in cellular energy metabolism and cell death. Deregulation of mitochondrial functions is associated with several human pathologies (neurodegenerative diseases, neuromuscular diseases, type II diabetes, obesity, cancer). The steadily increasing number of identified mitochondrial phosphoproteins, kinases and phosphatases in last years suggests that reversible protein phosphorylation plays an important part in the control of mitochondrial processes. In addition, many mitochondrial phosphoproteins probably still remain to be identified, considering that $30 \%$ of proteins are expected to be phosphorylated in eukaryotes. In this chapter, we describe two procedures for the analysis of the mitochondrial phosphoproteome. The first one is a qualitative method that combines Blue native and Sodium Dodecyl Sulfate - PolyAcrylamide Gel Electrophoresis (2D -BN /SDS-PAGE) and specific phosphoprotein staining. The second one is a quantitative approach that associates mitochondrial peptide labelling, phosphopeptide enrichment and mass spectrometry.

Keywords: Saccharomyces cerevisiae, mitochondria, phosphoproteome

\section{Introduction}

Phosphorylation is the most frequent post-translational modification: $30 \%$ of the proteins are phosphorylated at some point during their cell cycle (1). This is a reversible process which varies especially during environmental changes $(\mathbf{2}, \mathbf{3})$, the cell cycle $(\mathbf{4})$, stress, or a nutritional change (5), suggesting a role of phosphorylation in environmental adjustment. A large number of phosphorylated mitochondrial proteins have been identified and phosphorylation appears involved in various functions such as transcription, apoptosis or energy metabolism (6).

As mitochondria are a small cellular compartment, their isolation is necessary for the analysis of their phosphoproteome. This is illustrated by the work of Amoutzias et al. (7), who summarized several phosphoproteomic studies performed on yeast cells: they listed more than 10000 sites of phosphorylation but only about one hundred were located on mitochondrial proteins. Phosphoproteomic analysis were developed using either labelling techniques with ${ }^{32} \mathrm{P}(\mathbf{8})$, detection with phosphoantibodies, fluorescent labelling with ProQ Diamond (9) or phosphorylated peptide enrichment $(\mathbf{1 0}, \mathbf{1 1})$. In all the cases, the identification of the phosphorylated residue required analysis by mass spectrometry.

Analysis by mass spectrometry allowed a significant improvement of the knowledge of mitochondrial phosphoproteome in various organisms. However, phosphorylated proteins remain less abundant than their non-phosphorylated counterparts and the ionization of phosphopeptides is less effective than non-phosphorylated peptides, making their detection by mass spectrometry more difficult. Phosphoproteome analysis therefore requires specific analysis techniques, in particular enrichment in phosphopeptides upstream of the LC-MS / MS. The most widely used methods of enrichment are the Immobilized Metal ion Affinity Chromatography (IMAC)(10) which is based on the high affinity of phosphates to certain trivalent metal ions, and metal oxide chromatography (MOC) (11) using the titanium dioxide $\left(\mathrm{TiO}_{2}\right)$ or zirconium dioxide $\left(\mathrm{ZrO}_{2}\right)$. To optimize this enrichment step, the samples are prefractionated, either by SDS-PAGE, or by chromatography such as Strong Cation Exchange Chromatography (SCX) or hydrophilic interaction liquid chromatography (HILIC) (12). 
These different strategies are optimal for the analysis of phosphorylated serines and threonines. Because of their presence in small quantities, phospho-tyrosines are often analysed after specific enrichment such as immunoprecipitation using an antibody against phospho-tyrosine (13). Histidine phosphorylation is not detected by standard LC-MS / MS analyzes, because they are generally conducted at acidic $\mathrm{pH}$, at which phosphorylation is labile for this residue. The detection of this phosphorylated residue thus requires specific analysis strategy (14).

Finally, quantitative phosphoproteomic analysis can be performed using i) labelling methods either metabolic labelling (SILAC) (15) or chemical labelling (iTRAQ (16), multiplex stable isotope dimethyl labelling (17)) ii) Single Reaction Monitoring/ Multiple Reaction Monitoring (SRM/MRM) analysis (18).

In this chapter, we present two techniques (presented schematically in fig.1) that we have carried out on isolated mitochondria to analyse protein phosphorylation state. The first one relies on Blue native and Sodium Dodecyl Sulfate - PolyAcrylamide Gel Electrophoresis (2D -BN /SDS-PAGE) associated to Pro-Q Diamond staining (sections 3.1 and 3.3 to 3.5). The second one is quantitative and uses multiplex stable isotope dimethyl labelling followed by fractionation by SCX and phosphopeptides enrichment by IMAC before LC-MS/MS analysis (sections 3.1, 3.2 and 3.6 to 3.9). This second approach allowed us to produce the first extensive study providing quantitative data on phosphosite responses to different carbon substrates in the yeast Saccharomyces cerevisiae (19).

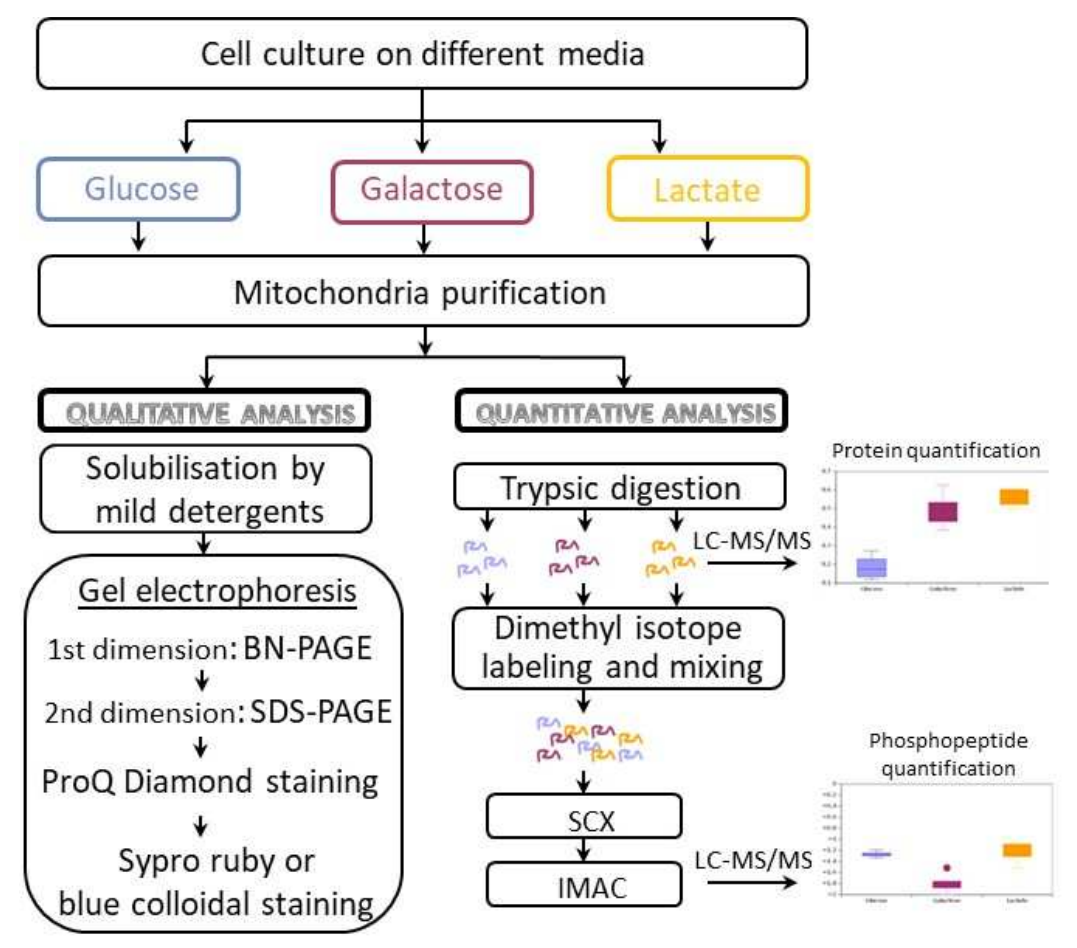

Fig.1: Scheme of two experimental approaches for the phosphoproteomic analysis of isolated mitochondria. Starting with pure yeast mitochondria, the qualitative approach permits to reveal the presence of phosphoproteins in the different complexes separated by BN-PAGE, while the quantitative approach allows the analysis of phosphopeptide abundance variations. 


\section{Materials}

Prepare all solutions using ultrapure water (sensitivity $18 \mathrm{M} \Omega \mathrm{cm}$ at $25^{\circ} \mathrm{C}$ ).

\subsection{Cell culture}

Yeast WT strain was grown in galactose, glucose or lactate media (see Note 1).

1. Medium 1: $1.25 \%(\mathrm{w} / \mathrm{w})$ bacto yeast extract, $2.5 \%(\mathrm{w} / \mathrm{w})$ bactopeptone. Weigh $5 \mathrm{~g}$ of bacto yeast extract and $10 \mathrm{~g}$ of bactopeptone. Complete to a volume of $400 \mathrm{~mL}$ with water. Autoclave at $120^{\circ} \mathrm{C}, 20 \mathrm{~min}$.

2. $10 \%$ galactose: weigh $10 \mathrm{~g}$ of galactose. Complete to a volume of $100 \mathrm{~mL}$ with water. Autoclave at $120^{\circ} \mathrm{C}, 20 \mathrm{~min}$.

3. $10 \%$ glucose: weigh $10 \mathrm{~g}$ of glucose. Complete to a volume of $100 \mathrm{~mL}$ with water. Autoclave at $120^{\circ} \mathrm{C}, 20 \mathrm{~min}$.

4. Galactose medium: $1 \%(\mathrm{w} / \mathrm{w})$ bacto yeast extract, $2 \%(\mathrm{w} / \mathrm{w})$ bactopeptone, $2 \%$ $(\mathrm{w} / \mathrm{w})$ galactose. Just before use, mix $400 \mathrm{~mL}$ of medium 1 and $100 \mathrm{~mL}$ of $10 \%$ galactose.

5. Glucose medium: $1 \%(\mathrm{w} / \mathrm{w})$ bacto yeast extract, $2 \%(\mathrm{w} / \mathrm{w})$ bactopeptone, $2 \%$ $(\mathrm{w} / \mathrm{w})$ glucose. Just before use, mix $400 \mathrm{~mL}$ of medium 1 and $100 \mathrm{~mL}$ of $10 \%$ glucose.

6. Lactate medium: $0.5 \%(\mathrm{v} / \mathrm{v})$ lactic acid, $0.75 \%(\mathrm{w} / \mathrm{w})$ bacto yeast extract, $0.75 \%$ (w/w) bactopeptone. Sample $5.9 \mathrm{~mL}$ of lactic acid. Add $800 \mathrm{~mL}$ of water. Adjust the $\mathrm{pH}$ to 4 with a solution of $10 \mathrm{~N} \mathrm{KOH}$. Then add $7.5 \mathrm{~g}$ of bactopeptone and $7.5 \mathrm{~g}$ of bacto yeast extract. Check the $\mathrm{pH}$ to be 4.5 . Add water to a volume of $1 \mathrm{~L}$. Autoclave at $120^{\circ} \mathrm{C}, 20 \mathrm{~min}$.

\subsection{Preparation of mitochondria by differential centrifugation}

1. DTT buffer: $100 \mathrm{mM}$ TRIS-H $\mathrm{SO}_{4} \mathrm{pH} 9.4$ and $10 \mathrm{mM}$ DTT (see Note 2).

2. 0.1M Potassium phosphate buffer $\mathrm{pH}$ 7.4: $\mathrm{mix} 80.2 \mathrm{~mL}$ of $1 \mathrm{M} \mathrm{K}_{2} \mathrm{HPO}_{4}$ and $19.8 \mathrm{~mL}$ of $1 \mathrm{M} \mathrm{KH} \mathrm{H}_{2} \mathrm{PO}_{4}$. Complete to a volume of $1 \mathrm{~L}$ with water.

3. Zymolyase buffer: 1 . 2M sorbitol, $20 \mathrm{mM}$ potassium phosphate, $\mathrm{pH} 7.4$.

4. Zymolyase-20T.

5. PMSF $100 \mathrm{mM}$ : weigh $17.4 \mathrm{mg}$ of PMSF in $1 \mathrm{~mL}$ of ethanol. (see Note 3 )

6. Homogenization buffer: 0.6M sorbitol, $10 \mathrm{mM}$ TRIS-HCl pH7.4, $1 \mathrm{mM}$ EDTA, PMSF 1mM. 


\subsection{Preparation of mitochondria purified on sucrose gradient}

1. SEM buffer: $250 \mathrm{mM}$ sucrose, $1 \mathrm{mM}$ EDTA, 10mM MOPS-KOH pH 7.2

Weigh $2.57 \mathrm{~g}$ of sucrose. Add $3 \mathrm{~mL}$ of $100 \mathrm{mM}$ MOPS-KOH pH 7.2 and 100 $\mu \mathrm{L}$ of 0.3M EDTA pH 7.4. Complete to a volume of $30 \mathrm{~mL}$ with water.

2. EM buffer: $1 \mathrm{mM}$ EDTA, 10mM MOPS-KOH pH 7.2

Add $100 \mathrm{~mL}$ of $100 \mathrm{mM}$ MOPS-KOH pH 7.2 and $3.33 \mathrm{~mL}$ of $0.3 \mathrm{M}$ EDTA pH 7.4. Add water to a volume of $1 \mathrm{~L}$.

3. Solutions for sucrose gradient:

$3.160 \%$ sucrose solution: weigh $12 \mathrm{~g}$ of sucrose and add EM buffer to a volume of $20 \mathrm{~mL}$.

$3.232 \%$ sucrose solution: weigh $16 \mathrm{~g}$ of sucrose and add EM buffer to a volume of $50 \mathrm{~mL}$.

3.3. $23 \%$ sucrose solution: weigh $4.6 \mathrm{~g}$ of sucrose and add EM buffer to a volume of $20 \mathrm{~mL}$.

$3.415 \%$ sucrose solution: weigh $3 \mathrm{~g}$ of sucrose and add EM buffer to a volume of $20 \mathrm{~mL}$.

\subsection{Solubilisation of mitochondria}

1. Gel Buffer (3x): $1.5 \mathrm{M} \varepsilon$-amino-n-caproic acid 0.5M, $150 \mathrm{mM}$ Bis-Tris. The $\mathrm{pH}$ is adjusted to 7 with $\mathrm{HCl}$ at $4^{\circ} \mathrm{C}$. The buffered is filtered on $0.45 \mu \mathrm{m}$ filter.

2. DNAse solution: $0.2 \mathrm{mg} / \mathrm{mL}$ DNAse, $5 \mathrm{mM} \mathrm{MgCl}_{2}$ and $1 \mathrm{mM}$ PMSF were added in gel buffer (x3).

3. Solubilization buffer: $2 \%$ laurylmaltoside (weight/volume) or $2 \%$ digitonine (weight/volume) were prepared in gel buffer (x3).

\subsection{BN/ SDS PAGE - 2D electrophoresis}

\subsubsection{D-electrophoresis - First dimension: BN-PAGE}

1. Acrylamide/Bis solution: $40 \%$ solution $29: 1$

2. Ammonium persulfate: prepare a $10 \%(\mathrm{w} / \mathrm{v})$ solution in water and store at $4^{\circ} \mathrm{C}$ for up to one month.

3. 5\% acrylamide solution: Mix $625 \mu \mathrm{L}$ of acrylamide:bis-acrylamide solution and $1.67 \mathrm{~mL}$ of gel buffer (x3). Complete to $5 \mathrm{~mL}$ with $\mathrm{H}_{2} \mathrm{O}$. Add $3 \mu \mathrm{L}$ of Temed and $30 \mu \mathrm{L}$ of $10 \%$ ammonium persulfate. 
4. $10 \%$ acrylamide solution: Mix $1.3 \mathrm{~mL}$ of acrylamide:bis-acrylamide solution and $1.67 \mathrm{~mL}$ of gel buffer (x3). Complete to $5 \mathrm{~mL}$ with $\mathrm{H}_{2} \mathrm{O}$. Add $2.5 \mu \mathrm{L}$ of Temed and $25 \mu \mathrm{L}$ of $10 \%$ ammonium persulfate.

5. Stacking gel (3\%): Mix $375 \mu \mathrm{L}$ of acrylamide: bis solution and $1.67 \mathrm{~mL}$ of gel buffer (x3). Complete to $5 \mathrm{~mL}$ with $\mathrm{H}_{2} \mathrm{O}$. Add $5 \mu \mathrm{L}$ of Temed and 50 $\mu \mathrm{L}$ of $10 \%$ ammonium persulfate.

6. Cathode buffer A: $15 \mathrm{mM}$ Bis-Tris, $50 \mathrm{mM}$ Tricine. The $\mathrm{pH}$ is adjusted to 7.0 with a concentrated $\mathrm{HCl}$ solution at $4{ }^{\circ} \mathrm{C}$. The buffer is filtered on Millipore $0.45 \mu \mathrm{m}$ filter. Then $0.02 \%$ (w/v) Serva Blue G-250 is added and the buffer is sonicated in a bath sonicator to solubilize the Serva Blue G250.

7. Cathode buffer B: same as cathode buffer A except that no Serva Blue G250 is added.

8. Anode buffer: $50 \mathrm{mM}$ Bis-Tris. The $\mathrm{pH}$ is adjusted to 7.0 with a concentrated $\mathrm{HCl}$ solution at $4^{\circ} \mathrm{C}$. The buffer is filtered on $0.45 \mu \mathrm{m}$ filter.

9. Molecular weight markers: High Molecular Weight Calibration Kit for Native Electrophoresis.

\subsubsection{D-electrophoresis - Second dimension: SDS-PAGE}

1. Acrylamide/Bis solution: $40 \%$ solution $37.5: 1$.

2. Resolving gel buffer: $3 \mathrm{M}$ Tris- $\mathrm{HCl} \mathrm{pH} 8.8$. Weigh $363 \mathrm{~g}$ Tris. Add water to a volume of $700 \mathrm{~mL}$. Mix and adjust $\mathrm{pH}$ to 8.8 with $\mathrm{HCl}$. Complete to $1 \mathrm{~L}$ with water. Filter through a $0.45 \mu \mathrm{m}$ filter. Store at $4^{\circ} \mathrm{C}$.

3. Stacking gel buffer: $0.5 \mathrm{M}$ Tris- $\mathrm{HCl}, \mathrm{pH} 6.8$. Weigh $60.5 \mathrm{~g}$ Tris and prepare a $1 \mathrm{~L}$ solution as in previous step. Filter through a $0.45 \mu \mathrm{m}$ filter. Store at $4^{\circ} \mathrm{C}$.

4. $10 \%$ acrylamide solution: Measure $2.5 \mathrm{~mL}$ of acrylamide: bis-acrylamide solution and $1.25 \mathrm{~mL}$ of Tris- $\mathrm{HCl} 3 \mathrm{M} \mathrm{pH} 8.8$. Add $3 \mu \mathrm{L}$ of Temed and 30 $\mu \mathrm{L}$ of $10 \%$ ammonium persulfate. Complete with $\mathrm{H}_{2} \mathrm{O}$ to a volume of 10 $\mathrm{mL}$.

5. $20 \%$ acrylamide solution: Measure $5 \mathrm{~mL}$ of acrylamide: bis-acrylamide solution and $1.25 \mathrm{~mL}$ of Tris- $\mathrm{HCl} 3 \mathrm{M}$ pH8.8. Add $2.5 \mu \mathrm{L}$ of Temed and $22.5 \mu \mathrm{L}$ of $10 \%$ ammonium persulfate. Complete with $\mathrm{H}_{2} \mathrm{O}$ to a volume of $10 \mathrm{~mL}$.

6. Stacking gel (5\%): Measure $1.5 \mathrm{~mL}$ of acrylamide: bis-acrylamide solution and $3 \mathrm{~mL}$ Tris-HCl $0.5 \mathrm{M}$ pH 6.8. Add $20 \mu \mathrm{L}$ of Temed and $200 \mu \mathrm{L}$ of $10 \%$ ammonium persulfate. Complete with $\mathrm{H}_{2} \mathrm{O}$ to a volume of $12 \mathrm{~mL}$.

7. Tris- glycine (x5) buffer: Tris $250 \mathrm{mM}$ and glycine $1.92 \mathrm{M} \mathrm{pH} 8.8$. Weigh $60.5 \mathrm{~g}$ Tris and $288 \mathrm{~g}$ of glycine. Complete with $\mathrm{H}_{2} \mathrm{O}$ to a volume of $2 \mathrm{~L}$. $\mathrm{pH}$ will be around 8.8 without any adjustement.

8. Cathode Buffer: $50 \mathrm{mM}$ Tris, $384 \mathrm{mM}$ Glycine, 0.1\% SDS, $1 \mathrm{mM}$ EDTA: dilute $x 5$ Tris-glycine (x5) buffer and add $0.1 \%$ SDS (w/v) and $1 \mathrm{mM}$ EDTA.

9. Anode Buffer: $50 \mathrm{mM}$ Tris, $384 \mathrm{mM}$ Glycine; dilute x5 Tris-glycine (x5) buffer

10. Molecular weight markers: Precision Plus Protein Standards, dual color. 


\subsection{Phosphoproteins staining}

1. ProQ Diamond stain.

2. Fixation solution: $50 \%$ methanol, $10 \%$ acetic acid, $40 \%$ water (see Note 4).

3. Discoloration solution: $50 \mathrm{mM}$ ammonium acetate, $20 \%$ acetonitrile, $80 \%$ water.

4. Molecular Weight Standards: Peppermintstick Phosphoprotein.

\subsection{Proteins staining}

After phosphoproteins staining, proteins could be stained either with Sypro Ruby protein gel stain or Coomassie Blue protein gel stain.

1. Syproruby stain.

2. Discoloration solution: $7 \mathrm{M}$ acetic acid, $10 \%$ methanol, $83 \%$ water.

3. Coomassie Blue stain.

\subsection{Preparation and labelling of mitochondrial peptides for quantitative mass spectrometry experiment}

2.8.1. Digest sample

1. Zwitterionic acid labile surfactant ZALS I.

2. Ammonium bicarbonate $\left(\mathrm{NH}_{4} \mathrm{HCO}_{3}\right)$.

3. ZUT buffer : $0.1 \%$ ZALS I solubilised in $50 \mathrm{mM} \mathrm{NH}_{4} \mathrm{HCO}_{3}, 6 \mathrm{M}$ urea, $2 \mathrm{M}$ thiourea, $30 \mathrm{mM}$ Tris- $\mathrm{HCl} \mathrm{pH} 8.8,10 \mathrm{mM}$ DTT.

4. 2D Quant kit.

5. Sequencing grade modified trypsin.

6. Trypsin digestion: trypsin/protein ratio: $1 / 30$.

7. Trifluoroacetic acid.

8. Vacuum centrifuge (Speed vac concentrator)

\subsubsection{Stable isotope dimethyl labeling of trypsic peptides}

! CAUTION Formaldehyde solutions and formaldehyde vapors are toxic; prepare solutions in a fume hood.

1. Formaldehyde solution for molecular biology, (36.5-38\% in $\left.\mathrm{H}_{2} \mathrm{O}\right)$.

2. Formaldehyde (CD2O) $(20 \%, 98 \%$ D).

3. Formaldehyde (13CD2O) $(20 \%, 99 \% 13 \mathrm{C}, 98 \%$ D).

4. Sodium cyanoborohydride $(\mathrm{NaBH} 3 \mathrm{CN})$.

5. Sodium cyanoborodeuteride ( $\mathrm{NaBD} 3 \mathrm{CN})$.

6. Sodium phosphate buffer $\mathrm{pH} 7.5$ : mix $1 \mathrm{~mL}$ of $50 \mathrm{mM} \mathrm{NaH}_{2} \mathrm{PO}_{4}$ with $3.5 \mathrm{~mL}$ of $50 \mathrm{mM} \mathrm{Na} \mathrm{HPO}_{4}$; Sodium phosphate monobasic $\left(\mathrm{NaH}_{2} \mathrm{PO}_{4}\right)$. Sodium phosphate dibasic $\left(\mathrm{Na}_{2} \mathrm{HPO}_{4}\right)$.

7. Light labelling solution: Add $5 \%(\mathrm{v} / \mathrm{v})$ formaldehyde $4 \%, 5 \%(\mathrm{v} / \mathrm{v})$ cyanoborohydride $0.6 \mathrm{M}$ in $50 \mathrm{mM}$ sodium phosphate buffer $\mathrm{pH} 7.5$. 
8. Intermediate labelling solution: Add 5\% (v/v) formaldehyde ${ }^{2} \mathrm{D} 4 \%, 5 \%$ $(\mathrm{v} / \mathrm{v})$ cyanoborohydride $0.6 \mathrm{M}$ in phosphate buffer $\mathrm{pH}$ 7.5.

9. Heavy labelling solution: Add $5 \%$ (v/v) formaldehyde ${ }^{2} \mathrm{D},{ }^{13} \mathrm{C} 4 \%, 5 \%$ (v/v) cyanoborodeutéride $0.6 \mathrm{M}$ in phosphate buffer $\mathrm{pH}$ 7.5.

10. Buffer A: $0.6 \%$ acetic acid in ultrapure water.

11. Buffer B: $0.6 \%$ acetic acid in $80 \%(\mathrm{v} / \mathrm{v})$ acetonitrile.

12. Sep-Pak C18 3 cc Vac RC Cartridge 500mg.

13. Vacuum manifold system.

14. Vacuum centrifuge (Speed vac concentrator).

! CRITICAL Labelling reagent mixtures should be kept at $4^{\circ} \mathrm{C}$ and not stored longer than $24 \mathrm{~h}$ to ensure labelling efficiency.

\subsection{Two-steps phosphopeptides enrichment}

\subsubsection{Strong cation exchange chromatography fractionation}

1. Buffer C: $30 \%(\mathrm{v} / \mathrm{v})$ acetonitrile, $0.5 \%(\mathrm{v} / \mathrm{v})$ formic acid in ultrapure water $(\mathrm{pH} 2.5)$

2. Buffer D: $30 \%(\mathrm{v} / \mathrm{v})$ acetonitrile, $0.5 \%(\mathrm{v} / \mathrm{v})$ formic acid and $540 \mathrm{mM}$ ammonium formate in ultrapure water $(\mathrm{pH} 4.7)$

3. HPLC: Ultimate LC system combined with a Famos autosampler and a Switchos II microcolumn switch system.

4. Collector: Probot system.

5. SCX column: Zorbax 300 SCX, 2.1mm ID x $150 \mathrm{~mm}$.

2.9.2 Enrichment of phosphopeptides by Immobilized Metal ion Affinity Chromatography (IMAC)

1. Buffer E (equilibration buffer): $30 \%$ (v/v) acetonitrile, $250 \mathrm{mM}$ acetic acid in water.

2. Buffer $\mathrm{F}$ (elution buffer): $30 \%(\mathrm{v} / \mathrm{v})$ acetonitrile, $0.4 \mathrm{M}$ ammonium hydroxide in water.

3. PHOS-Select iron affinity gel.

4. SigmaPrep Spin-Columns.

5. Centrifuge.

6. Vacuum centrifuge (Speed vac concentrator).

\subsection{LC-MS/MS analysis}

1. Buffer G: $2 \%$ acetonitrile, $0.05 \%$ trifluoroacetic acid and $0.05 \%$ formic acid.

2. Buffer $\mathrm{H}: 2 \%$ acetonitrile and $0.1 \%$ formic acid.

3. Buffer I: $0.1 \% \mathrm{AF} \mathrm{H}_{2} \mathrm{O} 100 \%$.

4. Buffer $\mathrm{J}: 0.1 \% \mathrm{AF} \mathrm{CH}_{3} \mathrm{CN} 100 \%$.

5. NanoHPLC : NanoLC-Ultra system.

6. Mass spectrometer: Q-Exactive mass spectrometer with a nano-electrospray interface.

7. Pre-column cartridge: PepMap $100 \mathrm{C} 18$ (particles of $5 \mu \mathrm{m}, 100 \mu \mathrm{m}$ i.d., $10 \mathrm{~mm}$ length).

8. Analytical column: PepMap $100 \mathrm{C} 18$ (particles of $3 \mu \mathrm{m} ; 75 \mu \mathrm{m}$ i.d., $150 \mathrm{~mm}$ length). 


\section{Methods}

\subsection{Preparation of mitochondria by differential centrifugation}

Yeast wild type strain is grown either in $2 \%$ glucose medium or $2 \%$ galactose medium to an $\mathrm{OD}_{600 \mathrm{~nm}}=6$, or $2 \%$ lactate medium to an $\mathrm{OD}_{600 \mathrm{~nm}}=4.5$.

The following protocol is the one developed by Meisinger et al. (20) with slight modifications.

1. Harvest the cells by centrifugation at $3000 \mathrm{~g}$ for $10 \mathrm{~min}$ at $4^{\circ} \mathrm{C}$ and wash with distilled water

2. Resuspend the cells in $2 \mathrm{~mL} / \mathrm{g}$ (wet weight) DTT buffer ( see Note 5) and shake at $30^{\circ} \mathrm{C}, 20 \mathrm{~min}$ in an incubator (Infors -120rpm)

3. Centrifuge at $3000 \mathrm{~g}, 5 \mathrm{~min}$

4. Wash the pellets in zymolyase buffer

5. Centrifuge at $3000 \mathrm{~g}, 5 \mathrm{~min}$

6. Resuspend the pellets in $7 \mathrm{~mL} / \mathrm{g}$ (wet weight) of zymolyase buffer

7. Digest the cell wall enzymatically with Zymolyase-20T at $3 \mathrm{mg} / \mathrm{g}$ of cells at $30^{\circ} \mathrm{C}$ for about $1 \mathrm{H}$. (see Note 6 )

8. Centrifuge at $3000 \mathrm{~g}, 5 \mathrm{~min}$ at $4^{\circ} \mathrm{C}$

9. Resuspend the pellets in $6.5 \mathrm{~mL} / \mathrm{g}$ (wet weight) of homogeneisation buffer (see Note 7)

10. Homogenize with 5 pestle strokes in a glass-teflon potter

11. Centrifuge at $1500 \mathrm{~g}, 5 \mathrm{~min}$ at $4^{\circ} \mathrm{C}$ to eliminate cell debris and nuclei

12. Keep the supernatant and centrifuge at $4000 \mathrm{~g}, 5 \mathrm{~min}$ at $4^{\circ} \mathrm{C}$

13. Keep the supernatant and centrifuge at $12000 \mathrm{~g}, 15 \mathrm{~min}$ at $4^{\circ} \mathrm{C}$ in order to harvest the crude mitochondria.

\subsection{Preparation of mitochondria purified on sucrose gradient}

Steps 1 to 4 follow the protocol developed by Meisinger et al. (20).

1. Resuspend the crude mitochondria pellet in $0.5 \mathrm{~mL}$ of SEM buffer containing $1 \mathrm{mM}$ PMSF, to have a final concentration of mitochondria of 5 $\mathrm{mg} / \mathrm{mL}$ approximately.

2. Homogenize the mitochondria with 10 up-and-down strokes in a Potter homogenizer and load on a three-step sucrose gradient $(1.5 \mathrm{~mL} 60 \%, 4 \mathrm{~mL} 32 \%$, $1.5 \mathrm{~mL} 23 \%$ and $1.5 \mathrm{~mL} 15 \%$ ).

3. Centrifuge the sucrose gradient at $134000 \mathrm{~g}$ at $4^{\circ} \mathrm{C}$ during $1 \mathrm{~h}$ in a SW41 Ti swinging bucket.

4. Collect the purified mitochondria at 60\%-32\% interface and resuspend in $1 \mathrm{~mL}$ of SEM buffer containing $1 \mathrm{mM}$ PMSF to have a final concentration of mitochondria of $1 \mathrm{mg} / \mathrm{mL}$ approximately.

5. Measure the protein concentration of purified mitochondria using the 2-D Quant Kit with BSA as a standard.

6. Aliquot the solution of purified mitochondria in $2 \mathrm{~mL}$ safe lock tubes. 
7. Centrifuge the aliquots at $14000 \mathrm{~g}$ at $4^{\circ} \mathrm{C}$ during $15 \mathrm{~min}$; throw the supernatants.

8. Then, in order to avoid degradation of proteins and to limit dephosphorylation events, precipitate the proteins by adding $2 \mathrm{~mL}$ of TCA $10 \%$ in each tube.

9. Homogenize the protein solutions by inversion of the tubes and incubate at $4^{\circ} \mathrm{C}$ during $15 \mathrm{~min}$.

10. Centrifuge the protein solutions at $14000 \mathrm{~g}$ at $4^{\circ} \mathrm{C}$ during $15 \mathrm{~min}$; throw the supernatants.

11. Add $2 \mathrm{~mL}$ of acetone $\left(-20^{\circ} \mathrm{C}\right)$ in every tube to eliminate the excess of TCA and transfer the protein solutions in Corex tubes.

10. Homogenize the protein solutions and centrifuge at $14000 \mathrm{~g}$ at $4{ }^{\circ} \mathrm{C}$ during 15 min; Throw the supernatants.

11. Dry the protein precipitates and store at $-20^{\circ} \mathrm{C}$.

\subsection{BN-PAGE/ SDS - 2D electrophoresis}

Method for non-denaturing gels was initially developed in (21)

\subsubsection{Solubilization of mitochondria}

1. Prior to their solubilisation, treat the mitochondria with DNAse: resuspend in order to have a final concentration of mitochondria equal to 1 $\mathrm{mg} / \mathrm{mL}$ in DNAse solution. Incubate the sample $30 \mathrm{~min}$ at $25^{\circ} \mathrm{C}$.

2. Centrifuge the sample at $13000 \mathrm{~g}$ at $4^{\circ} \mathrm{C}$ during $15 \mathrm{~min}$.

3. Resuspend the pellet of mitochondria in solubilisation buffer and incubate at $4^{\circ} \mathrm{C}$ during $30 \mathrm{~min}$.

4. Centrifuge the sample at $100000 \mathrm{~g}$ and at $4{ }^{\circ} \mathrm{C}$ during $30 \mathrm{~min}$. Throw the pellet.

5. Add Serva Blue $\mathrm{G}$ in the supernatant in order to have a final concentration of $0.25 \%$.

(See Note 8).

\subsubsection{Preparation of $B N-P A G E$}

1. Prepare a 5\%-10\% acrylamide gradient resolving gel in a $8 \mathrm{~cm} \times 6.5 \mathrm{~cm} \times 0.10 \mathrm{~cm}$ gel cassette.

2. Load a 3\% acrylamide stacking gel on the resolving gel. Then immediately insert a 10well gel comb.

3. Load the samples in the wells: the volume of samples is calculated to have $25 \mu \mathrm{g}$ of proteins/lane. After the loading of samples, completely fill the wells with cathode buffer A.

4. Perform electrophoresis at $4^{\circ} \mathrm{C}$.

5. During the first electrophoresis period, cathode buffer is buffer A. Perform electrophoresis at $100 \mathrm{~V}$ constant during $1 \mathrm{~h}$ then at $200 \mathrm{~V}$ constant during $1 \mathrm{~h}$ more. 
6. During the second electrophoresis period, cathode buffer is buffer B. Perform electrophoresis at $200 \mathrm{~V}$ until the dye front has reached the bottom of the gel.

\subsubsection{Preparation of the sample for the second dimension}

Immediately following BN-PAGE, cut a lane of interest and incubate it in $60 \mathrm{mM}$ $\mathrm{Na}_{2} \mathrm{CO}_{3}, 60 \mathrm{mM}$ DTT and 2\% SDS during 30 minutes.

\subsubsection{Preparation of SDS-PAGE}

1. Prepare a $10 \%-20 \%$ acrylamide gradient resolving gel in a $8 \mathrm{~cm} \times 5 \mathrm{~cm} \mathrm{x}$ $0.15 \mathrm{~cm}$ gel cassette.

2. Load a 5\% acrylamide stacking gel on the polymerised resolving gel. Insert a preparative comb containing a wide single well and a narrow reference. 3. Carefully load one BN-PAGE lane, previously incubated as described in 2.3.3., on the gel to avoid any bubble and pour the resolving gel on the lane. Load the protein standards in the reference well.

4. Perform electrophoresis at $4{ }^{\circ} \mathrm{C}$ and $120 \mathrm{~V}$ constant until the dye front has reached the bottom of the gel.

\subsection{ProQ Diamond staining (see Fig.2)}

1. Following electrophoresis, incubate the gel in the fixation solution, during $1 \mathrm{~h}$ at least.

2. Then, wash 3 times with water; each wash lasting 15 minutes.

3. Incubate with the Pro-Q Diamond during $2 \mathrm{~h}$ in the darkness.

4. Incubate three times in the discoloration solution in the darkness; each incubation lasting 30 minutes.

5. Wash 2 times with water in the darkness; each wash lasting 5 minutes.

6. Phosphoproteins are then detected by fluorescence detection: the excitation maximum of Pro-Q Diamond is at $550 \mathrm{~nm}$ and its emission maximum at $580 \mathrm{~nm}$. 


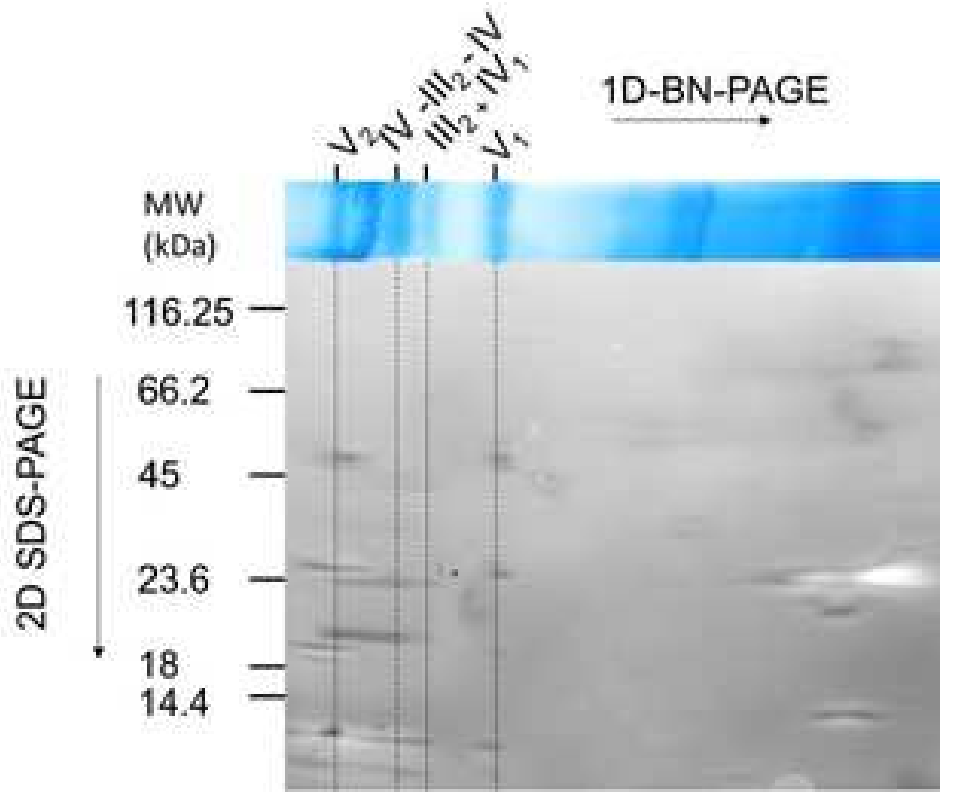

Fig.2: 2D BN /SDS-PAGE electrophoresis. Mitochondria were separated in the first dimension on BN-PAGE after digitonin solubilisation. Mitochondrial complexes (monomeric $\left[\mathrm{V}_{1}\right]$ and dimeric $\left[\mathrm{V}_{2}\right]$ complex $\mathrm{V}$ ) and supercomplexes (IV-III $2-\mathrm{IV}$ and $\mathrm{III}_{2}-\mathrm{IV}_{1}$ ) subunits are then separated in a second dimension on SDS-PAGE and phosphoproteins were detected after ProQ Diamond staining.

\subsection{Sypro Ruby staining}

1. Following Pro-Q Diamond detection, incubate the gel in Sypro Ruby during 1 night in the darkness.

2. Incubate three times in the discoloration solution in the darkness; each incubation lasting 30 minutes.

3. Wash 2 times with ultrapure in the darkness, each washing step lasting 5 minutes.

4. Proteins are then detected by fluorescence detection: the two excitation maxima of Sypro Ruby are at 280 and $450 \mathrm{~nm}$ and its emission maximum at $610 \mathrm{~nm}$.

\subsection{Preparation and labeling of mitochondrial peptides for quantitative mass spectrometry experiment}

\subsubsection{Suspension}

1. Dry the protein precipitates in corex tubes under vacuum during $15 \mathrm{~min}$.

2. Resuspend the proteins in $400 \mu \mathrm{L}$ of ZUT buffer in global, mix by vortex and apply short spin centrifuge (i.e. $200 \mathrm{rpm}$ ). Additional $200 \mu \mathrm{L}$ of ZUT buffer can be added if necessary (see Note 9).

3. Collect the protein solutions and measure the protein concentration with the 2D Quant kit 
1. Add $1 \mathrm{M}$ iodoacetamide in each sample to have a final concentration of iodoacetamide equal to $40 \mathrm{mM}$.

2. Incubate the samples $1 \mathrm{~h}$ in darkness.

\subsubsection{In-solution trypsin digestion}

1. Dilute the samples with 7 volumes of $50 \mathrm{mM}$ of ammonium bicarbonate.

2. Add trypsin in samples in order to have a trypsin/protein ratio of $1 / 30$.

Before its addition in samples, resuspend the trypsin with $50 \mathrm{mM}$ ammonium bicarbonate $(200 \mu \mathrm{L}$ ammonium bicarbonate for $40 \mu \mathrm{g}$ of trypsin).

3. Incubate the samples overnight at $37^{\circ} \mathrm{C}$.

4. Stop the digestion by addition of acid in order to reach $\mathrm{pH} 2$.

5. Dry the samples under vacuum using a speed vac.

\subsubsection{Stable isotope on column labelling}

The multiplex stable isotope dimethyl labelling procedure is those developed by Boeserma et al. (17)

! CAUTION Formaldehyde solutions and formaldehyde vapors are toxic; place the vacuum manifold in a fume hood. The vacuum manifold solvent liners should be inert and disposable to prevent carry-over between experiments.

1. Samples are suspended with formic acid 5\% (approximately $\mathrm{pH} 2$ ).

2. Labelling of samples is made on Sep-Pak C18 columns (see 2.7.2). The pressure must not exceed $5 \mathrm{mmHg}$ (vacuum manifold system). Columns are prepared with $2 \mathrm{~mL}$ of acetonitrile and $2 \times 2 \mathrm{~mL}$ of buffer $\mathrm{A}$.

3. Samples are loaded on columns

4. Columns are washed with $2 \mathrm{~mL}$ of buffer A.

5. Peptides fixed in the columns are labelled with $7 \times 1 \mathrm{~mL}$ of the appropriate labelling solution. For complete labeling, make sure that step takes at least $10 \mathrm{~min}$.

6. Columns are washed with $2 \mathrm{~mL}$ of buffer A.

7. Labelled peptides are eluted with $2 \times 500 \mu \mathrm{L}$ of buffer B.

8. Labelled peptides issued from different samples are mixed at a 1:1 ratio and dried by vacuum centrifugation. 


\subsection{Two-steps phosphopeptide enrichment}

\subsubsection{Strong exchange chromatography fractionation}

1. Prior to the phosphopeptides enrichment, separate the peptides with an SCX chromatography coupled to an UV detection system (flux: $200 \mu \mathrm{L} / \mathrm{min}$; run last 80 $\min )$.

2. Resuspend the labeled samples in $500 \mu \mathrm{l}$ of buffer $\mathrm{C}$.

3. Equilibrate the cation-exchange column by washing with buffer $\mathrm{C}$ (see Notes $\mathbf{1 0}$ and 11).

4. Load the sample on the column.

5. Wash with buffer $\mathrm{C}$, over $14 \mathrm{~min}$.

6. Elute the sample using a linear gradient from $0 \%$ to $65 \%$ of buffer D during $40 \mathrm{~min}$.

7. During the run, the occurrence of peptide at the outlet of the column is continuously analyzed with an on-line UV detection cell.

8. Systematically collect the eluted fraction in a 96-well sample collection plate (300 $\mu 1 /$ fraction).

9. Thanks to UV profile, select the wells where UV profile indicates the presence of peptides.

10. Mix the wells for a total of 12 fractions. Pooling too many wells would increase peptide concentrations in each extract and decrease the efficiency of the IMAC enrichment step. For the further steps, a fraction means a pool of 2 or 3 wells.

11. Lyophylize each fraction in a speed vac evaporator.

\subsubsection{Enrichment of phosphopeptides by Immobilized Metal ion Affinity Chromatography}

1. Before the phosphopeptides enrichment, PHOS-Select Iron affinity gel is prepared as following:

1.1. Homogenize the resin in glycerol

1.2. Centrifuge at $500 \mathrm{~g}$ and at room temperature during $2 \mathrm{~min}$ : supernatant is thrown

1.3. Resuspend the resin in the Equilibration buffer and washed 4 times with this buffer

2. Resuspend each fraction with $300 \mu \mathrm{L}$ of equilibration buffer and add $80 \mu \mathrm{L}$ of resin. Incubate 1 hour with mixing at room temperature (end over-end rotation recommended).

3. Load each fraction on one spin column and make a short spin centrifugation until $5000 \mathrm{~g}$.

4. Wash the spin column two times with $200 \mu \mathrm{L}$ of equilibration buffer and one time with $200 \mu \mathrm{L}$ of ultrapure water (short spin centrifugation until 5000g).

5. Elute the phosphopeptides with 2 x $30 \mu \mathrm{L}$ of elution buffer: make a first short spin centrifugation until 2000g and a second one until 14000g (see Note 12). 


\subsection{Phosphopeptide analysis LC-MS/MS}

1. Resuspend the fractions in $20 \mu \mathrm{l}$ of buffer $\mathrm{G}$.

2. Load $4 \mu \mathrm{L}$ at $7.5 \mu \mathrm{L} / \mathrm{min}$ on the pre-column cartridge with buffer $\mathrm{H}$.

3. Desalt the peptides with solvent I during 3 min.

4. Load the peptides on the analytical column and separate by a linear gradient from $5 \%$ to $30 \%$ buffer J during $37 \mathrm{~min}$ at $300 \mathrm{nl} / \mathrm{min}$.

5. Analyse the eluted peptides with mass spectrometer using Xcalibur 2.1 interface.

6. Data-dependent acquisition of peptide ions included a full MS scan covering the 300 to 1400 mass-to charge ratios $(\mathrm{m} / \mathrm{z})$ with a resolution of 70000 and a MS/MS step (normalized collision energy: 30\%; resolution: 17500). The MS/MS step was reiterated for the 8 major ions detected during the full MS scan. The dynamic exclusion was set to $45 \mathrm{~s}$.

\subsection{Bioinformatics Data Analysis}

1. Conversion of raw files to mzML format ( ProteoWizard software V3.0.3706).

2. Database searches process: use the XtandemPipeline (http://pappso.inra.fr/bioinfo/xtandempipeline/) to run database search with the $\mathrm{X}$ !Tandem search engine (22) and to manage redundancy (grouping of phosphopeptides and proteins harboring the same phosphosite(s)). Export data in MassChroQ format

3. Quantification: use the MassChroQ software (23) to quantify phosphopeptides according to their extracted ion current (XIC). Align LC-MS runs performed on the same SCX fraction number.

4. Computation of relative quantitative changes: for each phosphopeptide, compute the ratios between light, intermediary and heavy isotopes (if one of the isotopes is chosen as a reference, 2 ratios are computed, the reference being the common denominator). Normalize the ratios by dividing ratios by the median value of all phosphopeptide ratios within each triplex or duplex. Use log-transformed ratios for subsequent statistic tests.

5. When protein abundances were analysed in the same samples, phosphopeptide intensities can also be normalized by protein amounts, to take into account their possible variation in the computation of phosphopeptide quantitative changes.

\subsection{Conclusion}

The methods presented in this chapter are complementary means of studying the mitochondrial phosphoproteome. The qualitative method allows the analysis of the relation between the state of phosphorylation of proteins and their interaction with other proteins within a complex or within complexes interacting together (supercomplexes, for example). The quantitative method allows a comprehensive study on the state of phosphorylation of mitochondrial proteins independently from their possible interactions with each other, but allows the analysis of the effects of different conditions (carbon substrate, aerobic / anaerobic) or mutants. 


\section{Notes}

1. Cells were grown in liquid medium with shaking $(130 \mathrm{rpm})$ at $28^{\circ} \mathrm{C}$ in a standard incubator.

2. DTT buffer has to be prepared ex-temporarily.

3. PMSF is added in buffer just before its use; its stability in aqueous buffer solutions doesn't exceed $1 \mathrm{~h}$.

4. Be careful: methanol can't be substituted by ethanol.

5. Pre-equilibrate the DTT buffer at $30^{\circ} \mathrm{C}$ before use.

6 . The enzymatically cell wall digestion is followed by measurement of OD at $600 \mathrm{~nm}$, until it reaches $10 \%$ of the initial value.

7. Precool the homogenisation buffer at $4{ }^{\circ} \mathrm{C}$.

8. Solubilized mitochondria can be stored at $-20^{\circ} \mathrm{C}$ before loaded on BN-PAGE gel.

9. To simultaneously analyse different samples, concentrations of each sample are compared in order to have the same quantity of proteins in the different samples. If samples' volumes are not the same, they will be adjusted with ZUT buffer. 10. Start degassing buffer C and buffer D 30 min before the start of SCX chromatography.

11. Purge channels A and B, respectively connected to buffer C and buffer D, of the SCX chromatograph before its use.

12. The elution step in the IMAC enrichment protocol must be done quickly: in the presence of elution buffer, resin is not stable more than 5 minutes. 


\section{References}

1. Hunter, T. (1995) Protein Kinases and Phosphatases: The Yin and Yang of Protein Phosphorylation and Signaling. Cell 80, 225-236.

2. Schulze, W. X., Schneider, T., Starck, S., Martinoia, E. and Trentmann, O. (2012) Cold Acclimation Induces Changes in Arabidopsis Tonoplast Protein Abundance and Activity and Alters Phosphorylation of Tonoplast Monosaccharide Transporters. The Plant Journal 69, 529-541.

3. Bonhomme L, Valot B, Tardieu F, Zivy M. (2012) Phosphoproteome dynamics upon changes in plant water status reveal early events associated with rapid growth adjustment in maize leaves. Mol Cell Proteomics. 11, 957-72.

4. Tyanova, S., Cox, J., Olsen, J., Mann, M. and Frishman, D. (2013) Phosphorylation Variation during the Cell Cycle Scales with Structural Propensities of Proteins. PLoS Computational Biology 9, e1002842.

5. Oliveira, A. P., Ludwig, C. Picotti, P., Kogadeeva M, Aebersold R, and Sauer U. (2012) Regulation of Yeast Central Metabolism by Enzyme Phosphorylation. Molecular Systems Biology 8, 623.

6. Hofer, A., and Wenz, T. (2014) Post-Translational Modification of Mitochondria as a Novel Mode of Regulation. Experimental Gerontology. 56:202-20

7. Amoutzias, G.D., He, Y., Lilley, K.S., Van de Peer, Y. and Oliver, S.G. (2012) Evaluation and Properties of the Budding Yeast Phosphoproteome. Molecular \& Cellular Proteomics, 11, M111.009555.

8. Phillips, D., Hopper, R.K., Johnson, D.T., Harris, R.A., Blinova, K., Boja, E.S., French, S. and Balaban, R.S. (2009) Use of (32) P to study dynamics of the mitochondrial phosphoproteome. J Proteome Res. 8, 2679-95.

9. Schulenberg, B., Aggeler, R., Beechem, J.M., Capaldi, R.A., Patton, W.F. (2003) Analysis of steady-state protein phosphorylation in mitochondria using a novel fluorescent phosphosensor dye. J Biol Chem. 278, 27251-5.

10. Lee J., Xu Y., Chen Y., Sprung R., Kim S. C., Xie S., Zhao Y. (2007) Mitochondrial phosphoproteome revealed by an improved IMAC method and MS/MS/MS. Mol. Cell. Proteomics 6, 669-676

11. Beckers, G.J., Hoehenwarter, W., Röhrig, H., Conrath, U., Weckwerth, W. (2012)Tandem metal-oxide affinity chromatography for enhanced depth of phosphoproteome analysis. J Proteomics. 75, 4602-9.

12. Zarei, M., Sprenger,A., Metzger, F., Gretzmeier, C. and Dengjel, J. (2011) Comparison of ERLIC-TiO2, HILIC-TiO2, and SCX-TiO2 for Global Phosphoproteomics Approaches. Journal of Proteome Research 10, 3474-3483.

13. Lind, S. B., Artemenko, K.A.and Pettersson, U. (2012) A Strategy for Identification of Protein Tyrosine Phosphorylation. Methods 56, 275-283.

14. Besant, P. G, and Attwood, P.V. (2009)Detection and Analysis of Protein Histidine Phosphorylation. Molecular and Cellular Biochemistry 329, 93-106.

15. Ong, S.-E., Blagoev, B., Kratchmarova, I. Kristensen DB, Steen H, Pandey A, and Mann M. (2002) Stable Isotope Labeling by Amino Acids in Cell Culture, SILAC, as 
a Simple and Accurate Approach to Expression Proteomics. Molecular \& Cellular Proteomics 1, 376-386.

16. Boja, E.S., Phillips, D., French, S.A., Harris, R.A., Balaban, R.S. (2009) Quantitative mitochondrial phosphoproteomics using iTRAQ on an LTQ-Orbitrap with high energy collision dissociation. J Proteome Res. 8, 4665-75.

17. Boersema, P. J., Raijmakers, R., Lemeer, S., Mohammed, S. and Heck, A.J.R. (2009) Multiplex Peptide Stable Isotope Dimethyl Labeling for Quantitative Proteomics. Nature Protocols 4, 484-494.

18. Lam, M.P., Scruggs, S.B., Kim, T.Y., Zong, C., Lau, E., Ryan, C.M., Faull, K.F., Ping, P. (2014) An MRM-based workflow for quantifying cardiac mitochondrial protein phosphorylation in murine and human tissue. Methods Mol. Biol., 1072, 62132.

19. Renvoisé, M., Bonhomme, L., Davanture, M., Valot, B., Zivy, M. and Lemaire, C. (2014) Quantitative variations of the mitochondrial proteome and phosphoproteome during fermentative and respiratory growth in Saccharomyces cerevisiae. J. Proteomics, 106, 140-150.

20. Meisinger, C., Sommer, T. and Pfanner, N. (2000) Purification of Saccharomyces cerevisiae Mitochondria Devoid of Microsomal and Cytosolic Contaminations. Anal. Biochemistry, 287, 339-342.

21. Schagger, H. and von Jagow, G. (1991) Blue native electrophoresis for isolation of membrane protein complexes in enzymatically active form. Anal. Biochem., 199, 223231.

22. Craig, R., Beavis, R. C. (2004) TANDEM: matching proteins with tandem mass spectra. Bioinformatics, 20, 1466-1467.

23. Valot, B., Langella, O., Nano, E., Zivy, M., (2011) MassChroQ: A versatile tool for mass spectrometry quantification. Proteomics, 11 3572-3577. 